\title{
Colonization of the Corumbá Reservoir (Corumbá River, Paraná River Basin, Goiás State, Brazil) by the "lambari" Astyanax altiparanae (Tetragonopterinae; Characidae)
}

\author{
Rosa Maria Dias*, Dayani Bailly, Rosimeire Ribeiro Antônio, Harumi Irene Suzuki and \\ Angelo Antonio Agostinho \\ Nupelia/DBI; Programa de Pós-Graduação em Ecologia de Ambientes Aquáticos Continentais; Universidade \\ Estadual de Maringá; Av. Colombo, 5790; 87020-900; Maringá - PR - Brazil
}

\begin{abstract}
This work aimed to determine which population features were important to the colonization process of Astyanax altiparanae in the Corumbá Reservoir. The species presented wide spatial-temporal distribution, caught in all months and sites. Higher CPE values were recorded upstream from the reservoir during the filling phase. In this phase, reproductive activity was intense upstream and moderate in the tributaries. However, a fall in abundance of juveniles was observed after the formation of the reservoir. Among the most relevant population features to grant a successful colonization were wide geographic distribution, ability to occupy and spawn in lentic habitats and feeding flexibility.
\end{abstract}

Key words: Astyanax altiparanae, reservoir, colonization, reproduction

\section{INTRODUCTION}

Dammings have led to striking alterations in the physical, chemical and biological attributes of a river, with indirect influence on the ichthyofauna. Alteration in fish community structure, with the proliferation of sedentary species and the reduction or even elimination of migrators, is common to all dammings (Agostinho, 1992; Agostinho and Gomes, 1997). Even after the formation of the reservoir, non-cyclical disturbances related to the operation of the dam have been observed. In addition to contributing to community structure instability, they reduce species richness and stock size. This unstable situation restricts the types of organisms in reservoirs to those with great physiological tolerance and behavioral adaptability (Agostinho et al., 1999). Thus, the successional process progresses chaotically, resulting in the reduction in the interdependence between the species and in lower biotic stability (Wetzel, 1990). In the colonization process of new reservoirs, the most successful species are those with higher plasticity in their environmental demands, i.e. those having specific responses to the alteration dependents of the reproductive strategy (Rodrigues et al., 1995). Agostinho et al. (1999) report that small rapidly-developing eggs, high fecundity and feeding flexibility are possible Astyanax altiparanae pre-adaptations to the colonization of

* Author for correspondence 
reservoirs. Suzuki (1999) relates that species with more elaborate reproductive strategies encounter difficulties in the occupation of these environments and tend to decrease or even disappear in recentlyformed environments.

In general, Astyanax species are among the most resistant to the negative effects of dammings because they possess a wide feeding spectrum, small eggs with rapid development and ability to thrive in many different environments. Astyanax altiparanae, in particular, has been successful in the initial occupation and in the long term in reservoirs of the Paraná River Basin such as Rosana, Três Irmãos, Salto Caxias, Apucaraninha and Mourão (Agostinho et al., 1999; Luiz, 2000). In the first years of the formation of the Corumbá Reservoir, this species was among the most abundant (UEM-Nupelia, 2001).

In this work, we sought to discuss the population features related to the colonization success, analyzing abundance and reproduction data obtained before and after the construction of Corumbá Reservoir.

\section{STUDY AREA}

The Corumbá Reservoir, closed in September 1996, is located in the lower third of the Corumbá River, just above the backwater of the Itumbiara Reservoir (Paranaíba River) in the same river. The Corumbá River is one of the main tributaries of the right bank of the Paranaíba River, one of the two formers of the Paraná River. It is a plateau river with a $34.000 \mathrm{~km}^{2}$ drainage basin and in large part steep-banked with a narrow and rocky bed (Paiva, 1982).

The vegetation of the basin is classified as "cerrado", varying from open grasslands to forests and a tropical continental climate, with summer rains. Annual precipitation is above $1.500 \mathrm{~mm}$, with maximum values in January and minimum values in June. Annual average temperature is $20.5^{\circ} \mathrm{C}$, with minimum in July $\left(10^{\circ} \mathrm{C}\right)$ and maximum in October $\left(31.5^{\circ} \mathrm{C}\right)$, while relative humidity fluctuates between 45 (drought) and 85\% (rains) (UEM-NUPELIA, 1997). Dry period is from April to September and the wet is the other months (UEM-NUPELIA, 2001).

\section{MATERIALS AND METHODS}

Ichthyofauna samplings were carried out monthly in the area of influence of the Corumbá Reservoir from March 1996 to February 2000, covering the pre-damming (March 1996 - August 1996), filling (September 1996 - February 1997) and post-filling (March 1997 - February 2000) phases. The last phase was subdivided into post-1 (March 1997 February 1998), post-2 (March 1998 - February 1999) and post-3 (March 1999 - February 2000). When appropriate these phases are represented in the graphs. Samplings were carried out at 11 different sites grouped into three categories: reservoir - the Corumbá River channel in the stretch flooded after the damming, with 4 sampling sites (Pedra Lisa - LISA; Jacuba - JACU; Corumbá-Pirapitinga - CPIR; Ponte - PONT); upstream - the Corumbá River channel above the flooded area and composed of three sampling sites (Corumbá-Peixe - COPE; Moita - MOIT; Areia AREI); tributaries - two sites in the Pirapitinga River (PIRA; SAPE) and two in the Peixe River (LINI; PFOZ).

The fishing equipment used in the data collection consisted of gillnets with varying mesh sizes (2.4 to $16.0 \mathrm{~cm}$, measured diagonally between knots), operated on the surface and bottom of the reservoir sites and in the margins of the other sites. The nets were exposed at each site for 24 hours and examined at 7:00, 17:00 and 22:00. Seining nets (20 m long with $0.5-\mathrm{cm}$ meshes) were also operated for caught of individuals youngs $(<5 \mathrm{~cm})$.

The following data were recorded from each specimen caught: sampling date and site, fishing equipment, depth and catch period, specimen number, total length (Lt) and standard length (Ls) $(0.1 \mathrm{~cm})$, total weight $(\mathrm{Wt})(0.01 \mathrm{~g})$, sex, gonadal development stage (immature, beginning of maturation, maturing, mature, semi-spent, spent, recovery and rest, adapted from Vazzoler, 1996) and gonadal weight $(0.01 \mathrm{~g})$. Mature and semispent was considered "in reproduction".

Monthly average of the standard length $(\mathrm{cm})$ in different environments was calculated from fishes caugth with gillnets and seining nets. Species abundance was analyzed using catch per effort 
(CPE) values, expressed by the number of individuals caught in 24 hours per $1000 \mathrm{~m}^{2}$ of net.

The spatial and temporal variation in the reproductive activity of the species in the Corumbá River Basin (before and after the damming) were evaluated using the Index of Reproductive Activity (IRA; Suzuki and Agostinho, 1997), given by the equation:

$$
\operatorname{IRA}=\frac{\ln \mathrm{N}_{\mathrm{i}}\left(\frac{\mathrm{n}_{\mathrm{i}}}{\sum \mathrm{n}_{\mathrm{i}}}+\frac{\mathrm{n}_{\mathrm{i}}}{\mathrm{N}_{\mathrm{i}}}\right) \frac{\mathrm{GSR}_{\mathrm{i}}}{\mathrm{GSR}_{\mathrm{e}}}}{\ln \mathrm{N}_{\mathrm{m}}\left(\frac{\mathrm{n}_{\mathrm{m}}}{\sum \mathrm{n}_{\mathrm{i}}}+1\right)} \times 100
$$

Where $\mathrm{N}_{\mathrm{i}}=$ number of individuals in sample unit $\mathrm{i}$; $\mathrm{n}_{\mathrm{i}}=$ number of individuals "in reproduction" in sample unit $\mathrm{i} ; \mathrm{N}_{\mathrm{m}}=$ number of individuals in a sample unit with high $n ; n_{m}=$ number of individuals "in reproduction" in a sample unit with high n; $\mathrm{GSR}_{\mathrm{i}}=$ average GSR of individuals "in reproduction" in sample unit $\mathrm{i}: \mathrm{GSR}_{\mathrm{e}}=$ high individual value of GSR; GSR = gonadal weight*100/total weight. In this work, the reproductive activity of the species was classified as none (IRA $=0)$, incipient $(0<$ IRA $<5)$, moderate $(5 \leq$ IRA $<10)$ and intense (IRA $\geq 10)$. The differences in the considered variables were analyzed using a bifactorial ANOVA [Statistica ${ }^{\mathrm{TM}}$ in the GLM procedure (General Linear Models)], with phases and sites as factors.

\section{RESULTS}

Astyanax altiparanae showed wide spatialtemporal distribution in the area of influence of the Corumbá Reservoir, being caught in all months and at every site. Interaction between the factors (phases and sites) was not significant in the determination of abundance $(\mathrm{F}=0.97 ; \mathrm{p}=0.45)$; therefore, these results could be evaluated separately. The phases varied significantly among the analyzed sites $(\mathrm{F}=32.8 ; \mathrm{p}<0.001)$. The sites also had significant variation $(\mathrm{F}=8.04 ; \mathrm{p}<0.005)$. In the pre-damming phase, although occurring widely, the catches were, in general, low. After the damming, this species became very abundant in all considered sites categories, including stretches not directly affected by the damming. The highest catches per effort were recorded upstream from the reservoir during the filling period, falling gradually in the years that followed. The catches in the reservoir and tributaries were high and constant in the first two years after the filling, with a slight decrease in the third (Fig.1).

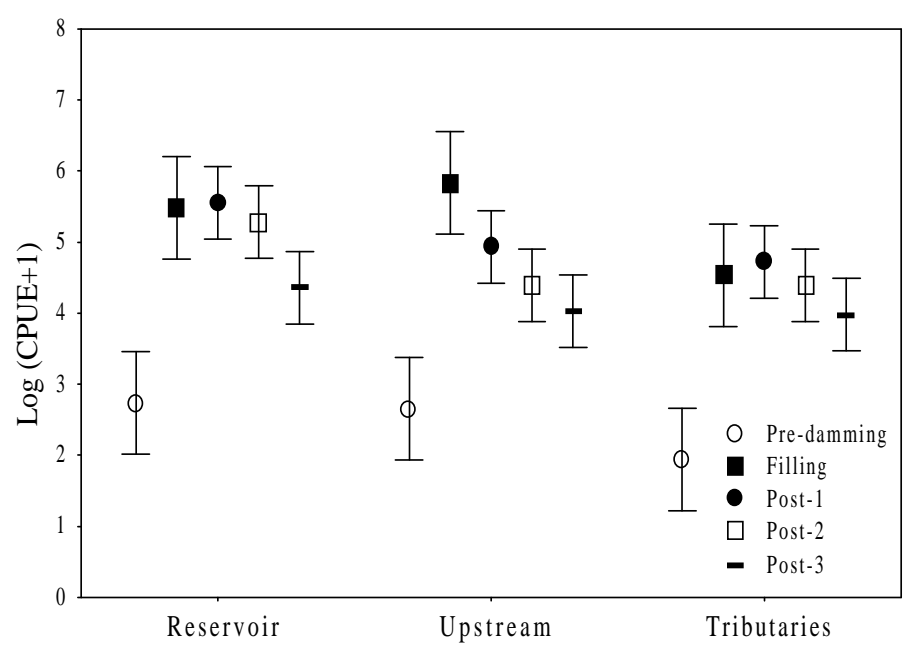

Figure 1 - Average catch values of Astyanax altiparanae in the different sites and phases analyzed. Vertical bar = average standard error. 
Seasonal fluctuations in abundance were verified, with the highest values being recorded from November to March of each year (Fig.2).

The standard length of the individuals caught during the period varied from 2.5 to $10.3 \mathrm{~cm}$, with the highest values being observed in the pre- damming phase in all the analyzed sites (Fig.3). In the subsequent phases, the average lengths of the individuals caught were shorter, indicating the high presence of youngs after the damming, mainly in the reservoir soon after the closing of the gates (Fig.4).
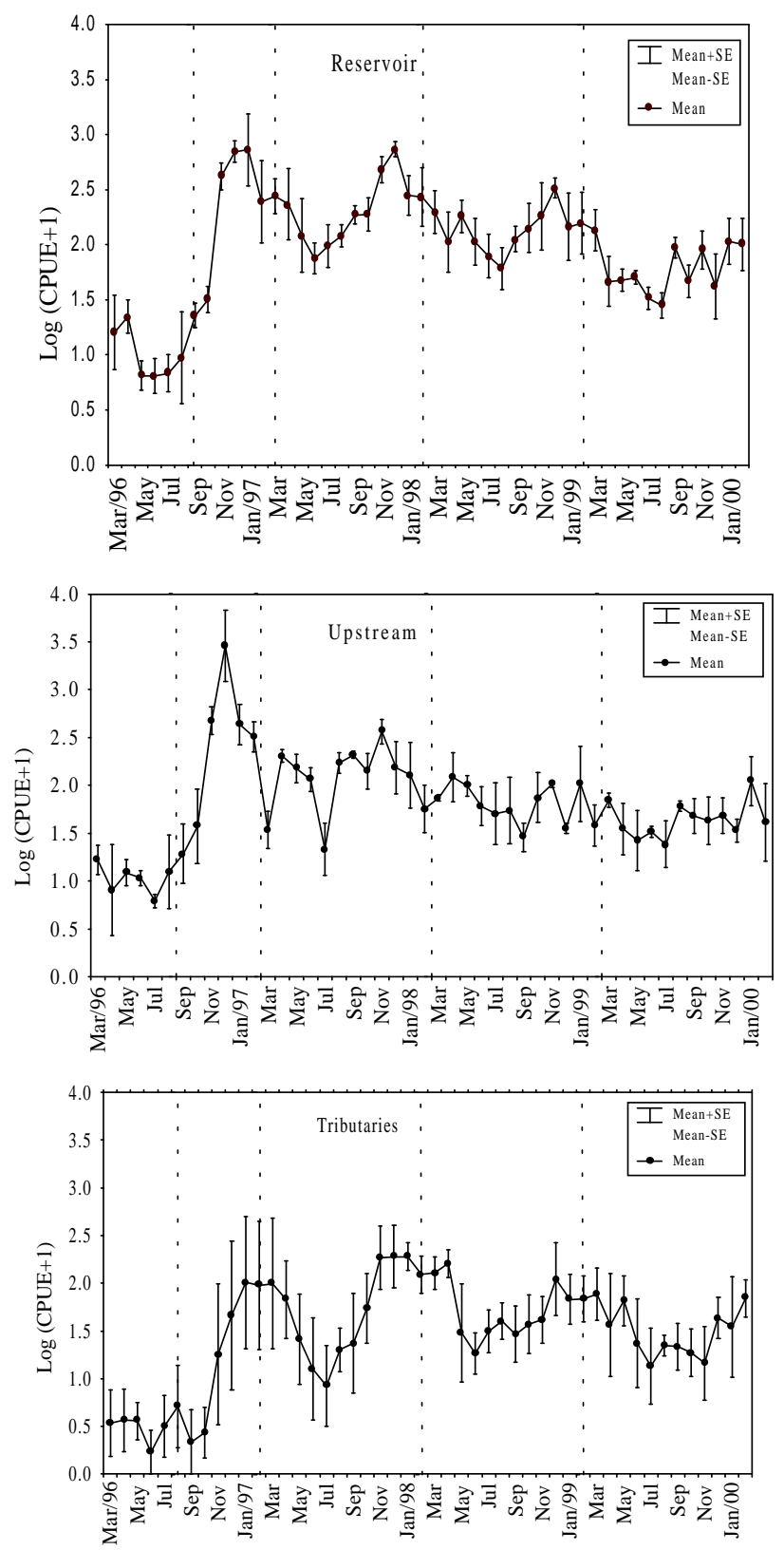

Figure 2 - Monthly catch variations in Astyanax altiparanae in the different sites considered. Vertical bar $=$ standard deviation. Vertical dotted lines delimitate impoundment phases.

The reproductive activity of $A$. altiparanae was relevant (moderate to intense) only at the sites outside the reservoir during the filling, started in September 1996, month of the dam closure. In the filling phase, reproductive activity was very intense in the stretches upstream from the reservoir and moderate in the tributaries (Fig.4). 
It was only incipient in the dammed area. In the first year after the damming, the opposite phenomenon was verified. In the other years, intense reproductions were recorded in all types of sites, with the most intense and lasting being in the reservoir (Fig.4). Despite the high reproductive activity in all sites, a fall in the abundance of young individuals was verified after the formation of the reservoir (Fig.4).
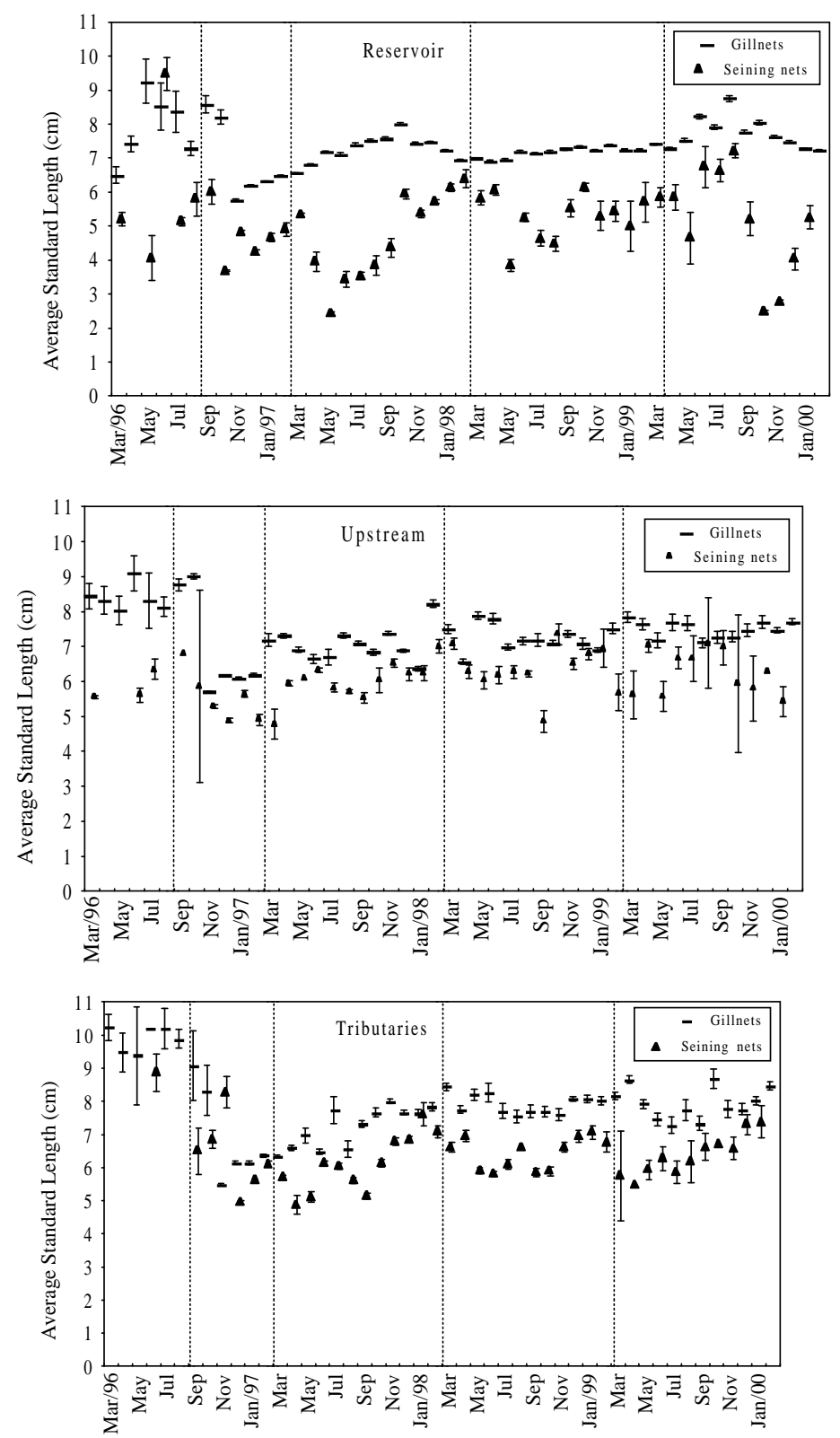

Figure 3 - Monthly average of the standard length $(\mathrm{cm})$ of Astyanax altiparanae in the different sites analyzed. Vertical bar $=$ standard deviation. Vertical dotted lines delimitate impoundment phases. 


\section{DISCUSSION}

Astyanax altiparanae was revealed to be a species with wide spatial-temporal distribution in the studied stretch of the Corumbá Reservoir, having been recorded at all sites and in every sampling month. The high ecological valence of this species has been reported at different sites, from streams to the channel of large rivers (Agostinho et al., 1984; Agostinho et al., 1997; Luiz et al., 1998; Agostinho and Julio Jr, 1999; Garutti and Britski, 2000; Abes and Agostinho, 2001) and from temporary lagoons to large artificial reservoirs (Arcifa et al., 1991; Agostinho et al., 1999; Okada et al., 2003). Its abundance in the pre-damming phase was low, with no relevant spatial variations. After the formation of the reservoir, the species became very abundant in the entire region, including stretches not affected by the impoundment. This suggested the success of the species in the colonization of the new environment and its high mobility in the region. Although the increase in abundance has been a generally-occurring phenomenon in the region, the intensity with which it occurred and its maintenance over the years were different. However, at the end of the period, species abundance remained high, and at a similar level different sites. Also, seasonal fluctuations in abundance were observed, with the highest values from November to March of each year. These periods of rain and higher temperatures showed that the seasonality in the catches was related to greater feeding and reproductive activity, as well as mobility, favoring catches using gillnets.

The higher catches per effort were observed in the stretch upstream from the reservoir during the filling phase. The adverse conditions connected to the decomposition of flooded organic material (anoxia of the deeper layers) probably led to massive population dislocations of this species to the stretches upstream during spawning. The fact that the species did not reproduce in the interior of the reservoir in this period, although capable of doing so, as demonstrated by the Index of Reproductive Activity values of subsequent years, showed the nature of this dislocation.

The studies on the diet of $A$. altiparanae in the Corumbá Reservoir (UEM-NUPELIA, 2001) demonstrated the opportunism of this species. In the first years after the formation of the reservoir, it fed on items as diverse as upper plants, terrestrial and aquatic insects, fishes, microcrustaceans, detritus and algae. The striking predominance of plants during this period contrasted with its essentially insectivorous diet on the Upper Paraná River floodplain (Hahn et al., 1997) and showed its feeding flexibility, demonstrating that its feeding strategy did not impose restrictions on reservoir occupation. Changes in the diet of Astyanax species were recorded by Fugi (1998) in the Segredo Reservoir (Iguaçu River). In relation to the morphological adaptations in the reservoir habitats, the striking presence of the species in the limnetic areas and margins at night and on the bottom during the day, as reported by UEM-NUPELIA (2001), showed its pre-adaptation to the hydrodynamic conditions of these habitats. Although native species that start to occupy reservoirs usually search for the most lotic stretches upstream from the reservoir or its lateral tributaries to spawn (Suzuki and Agostinho, 1997), Astyanax altiparanae seems to be more flexible in this requirement, spawning in lentic environments, including cultivation tanks (Andrade et al., 1985). Another reproductive aspect that was shown to be flexible was the spawning period. The duration of the reproductive period gradually became longer in the reservoir after the filling, with activity recorded during the entire year, probably reflecting the lower seasonality of the environmental conditions. Andrade et al. (1985) reported that the species could spawn in ponds between August and May. This process was more seasonal at the sites outside the reservoir, which also occured in other nonflooded environments of the basin, including marginal lagoons (Vazzoler et al., 1997). The variations in the spawning periods and the ability to spawn in lentic environments suggested that this species had the capacity to respond rapidly to environmental changes and high reproductive flexibility, contributing to its success in the colonization of new environments.

The high density of juveniles $(<5.0 \mathrm{~cm})$ in the reservoir in the months that followed the closure of the gates contrasted with the virtual absence of reproductive activity in this environment. These juveniles were, however, probably the result of the intense spawning that was observed at the upstream sites. They were carried to the interior of the reservoir, where the conditions of shelter and food 
availability resembled those after extraordinary floods in the downstream stretches of the Paraná River (Agostinho et al., 2000).

The average standard length of the individuals caught before the damming was longer in comparison to those caught after the closure of the dam. Rodrigues et al. (1989), analyzing the population structure of Astyanax bimaculatus at Bariri Reservoir (São Paulo State, Brazil), observed (over five years) a progressive increase in the catch of individuals of shorter length classes and a decrease in the catch frequency of individuals of longer length classes.
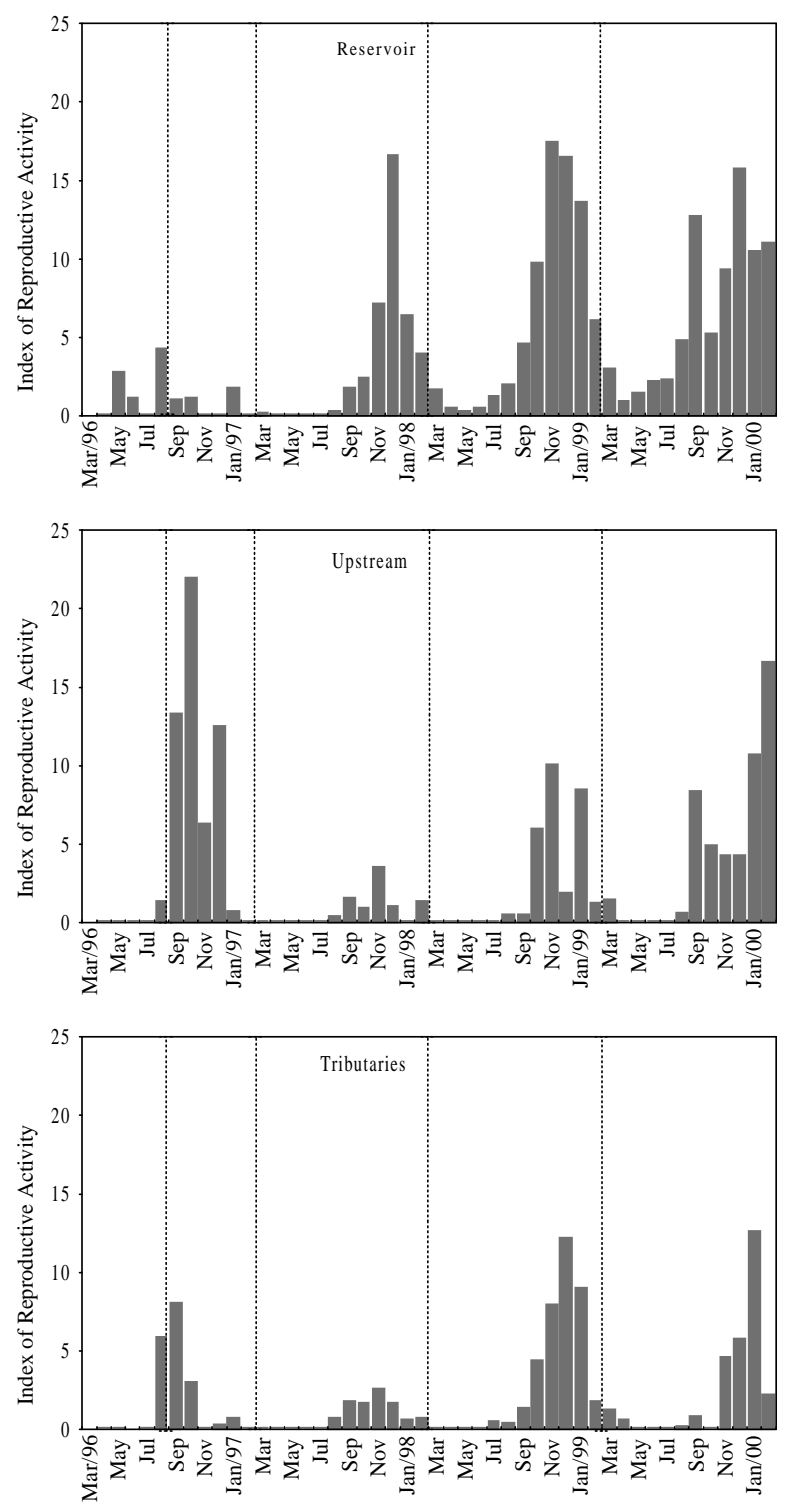

This was due to a reduction in trophic level, an increase in recruitment and a possible specific mortality of adult individuals associated with the fishery or pollution. In the present study, the fact that the reduction in the average length of the individuals caught in the littoral zone showed seasonality, with lower values between July and September, when the juveniles were more abundant, allowed one to attribute this variation to the recruitment of individuals young of the year.
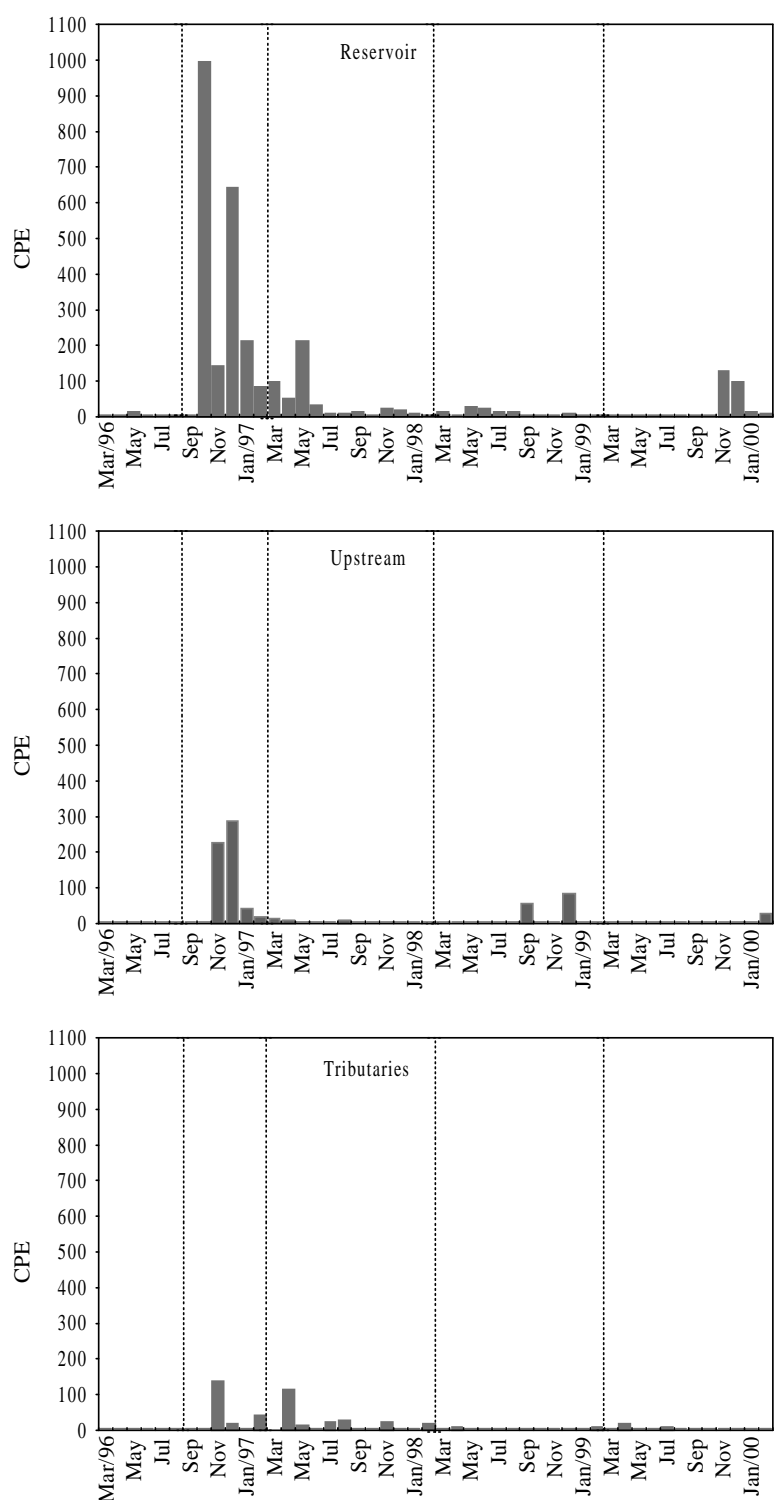

Figure 4 - Monthly variation in the values of the Index of Reproductive Activity (IRA; on the left) and in CPE (number of ind. $/ 1000 \mathrm{~m}^{2}$ of area) of individual youngs $(<5 \mathrm{~cm}$; on the right) of Astyanax altiparanae in the Corumbá Reservoir (Goiás State, Brazil). Vertical dotted lines delimitate impoundment phases. 
After the formation of the reservoir, the catch of youngs decreased, despite intense reproductive activity, suggesting that they were highly preyed in this phase. Cowan et al. (1997) attributed the main cause of larval mortality to predation. The increase in water transparency, facilitating the action of visual predators, and the extraordinary increase in predators such as Cichla monoculus ("tucunaré"), Galeocharax knerii ("peixe cadela") and juveniles of Salminus maxillosus ("dourado") beginning in the second year of the formation of the reservoir (UEM-NUPELIA, 2001), were indications of this process. During the first year of the reservoir the first two species presented intense reproductive activity, with a high incidence of juveniles (UEMNUPELIA, 2001). Although the "dourado" was not recorded in reproductive activity, it had a large increase in the abundance of its youngs in the dammed area. Almeida et al. (1997) studied the diet of predators of the Upper Paraná River floodplain and found that the main prey size ingested was approximately $5.0 \mathrm{~cm}$, with high participation of Astyanax bimaculatus (= A. altiparanae).

The high abundance of juveniles in the filling period of the reservoir should be related to the total catch maintenance of the species per effort in the two subsequent years. However, the conspicuous fall in abundance, observed in the subsequent year, was not proportional to that observed in the catches of the last year. This meant that the extraordinary reproductive success in the first year, result of an overlap of various events connected to the filling that favored the initial development of the species, was not sustained in the medium term. This phenomenon was, on the other hand, relevant to the success of upper trophic levels. Thus, the importance of the absolute abundance values of the juveniles to predict net gear abundance was relative, depending on predation.

The results obtained in this study shown that the Astyanax altiparanae characteristics most relevant to the successful colonization of reservoirs were wide geographic distribution, the ability to occupy and reproduce in lentic environments, and feeding flexibility. It was also observed that the closure of tropical reservoirs during fish reproduction could have a positive impact on the first spawn, given that the filling process simulated a large natural flood.

\section{ACKNOWLEDGMENTS}

Thanks are due to Nupélia (Research Nucleus in Lymnology, Ichthyology and Aquiculture) for collecting the material and logistical support and to Luiz Carlos Gomes PhD. for the valuable criticism and revision of text, Elaine Antoniassi Luiz M.Sc. helped analyses statistic data, Carlos Alexandre Fernandes for text format and Prof. John Jervis Stanley Junior for the English translation. The Project was sponsored by Furnas Centrais Elétricas.

\section{RESUMO}

$\mathrm{O}$ presente trabalho visa entender quais as características populacionais envolvidas no processo de colonização do Astyanax altiparanae no reservatório de Corumbá. As amostragens foram mensais, de março/1996 a fevereiro/2000, compreendendo as fases pré ((Março/1996Agosto/1996), enchimento (Setembro/1996Fevereiro/1997) e pós enchimento (Março/1997Fevereiro/2000), em 11 estações. A abundância foi obtida através da captura por unidade de esforço (CPUE). As variações espaciais e temporais na reprodução foram determinadas através do índice de atividade reprodutiva. A espécie apresentou ampla distribuição espaço temporal, sendo capturada em todos os meses e locais. Os maiores valores de CPUE foram registrados a montante, durante a fase de enchimento. Além disso, nesta fase, a reprodução foi muito intensa a montante do reservatório e moderada nos tributários. Entretanto, constatou-se uma queda na abundância de jovens após a formação do reservatório. Dentre as características populacionais mais relevantes para a colonização, destacam-se a ampla distribuição geográfica, habilidade de ocupar e reproduzir em habitats lênticos, além da flexibilidade alimentar. 


\section{REFERENCES}

Abes, S. S. and Agostinho, A. A. (2001), Spatial patterns in fish distributions and structure of the ichthyocenosis in the Água Nanci stream, upper Paraná river basin, Brazil. Hydrobiologia, 445, 217-227.

Agostinho, C. A.; Molinari, S. L.; Agostinho, A. A. and Verani, J. R. (1984), Ciclo reprodutivo e primeira maturação sexual de fêmeas do lambarí Astyanax bimaculatus (L.) (OsteichthyesCharacidae) do rio Ivaí, Estado do Paraná. Revista Brasileira de Biologia, 44, 31-36.

Agostinho, A. A. (1992), Manejo de recursos pesqueiros em reservatórios. In: Agostinho, A. A. and Benedito-Cecílio, E. (Eds.). Situação atual $e$ perspectivas da ictiologia no Brasil. Documentos do IX Encontro Brasileiro de Ictiologia. Maringá : EDUEM. pp. 106-121.

Agostinho, A. A.; Ferretti, C. M. L.; Gomes, L. C.; Hahn, N. S.; Suzuki, H. I.; Fugi, R. and Abujanra, F. (1997), Ictiofauna de dois reservatórios do rio Iguaçu em diferentes fases de colonização: Segredo e Foz do Areia. In: Agostinho, A. A. and Gomes, L. C. (Eds.). Reservatório de Segredo: bases ecológicas para o manejo. Maringá : EDUEM. pp. 275-292.

Agostinho, A. A. and Gomes, L. C. (1997), Manejo e monitoramento de recursos pesqueiros: perspectivas para o reservatório de Segredo. In: Agostinho, A. A. and Gomes, L. C. (Eds.). Reservatório de Segredo: bases ecológicas para o manejo. Maringá : EDUEM. pp. 319-364.

Agostinho, A. A. and Julio Junior, H. F. (1999), Peixes da bacia do alto rio Paraná. In: Lowe-McConnell, R. H. (Ed.). Estudos ecológicos de comunidades de peixes tropicais. São Paulo : EDUSP. pp. 374-400.

Agostinho, A. A.; Miranda, L. E.; Bini, L. M.; Gomes, L. C.; Thomaz, S. M. and Suzuki, H. I. (1999), Patterns of colonization in neotropical reservoirs, and prognoses on aging. In: Tundisi, J. G. and Straskraba, M. (Eds.). Theoretical reservoir ecology and its applications. São Carlos. pp. 227-265.

Agostinho, A. A.; Thomaz, S. M.; Minte-Vera, C. V. and Winemiller, K. O. (2000), Biodiversity in the high Paraná river floodplain. In: Gopal, B.; Junk, W. J. and Davis, J. A. (Eds.). Biodiversity in Wetlands: assessment, function and conservation. Backhuys Publishers, Leiden - The Netherlands, 1, 89-118.

Almeida, V. L. L.; Hahn, N. S. and Vazzoler, A. E. A. M. (1997), Feeding patterns in five predatory fishes of the high Paraná river floodplain (PR, Brazil). Ecology of Freshwater Fish., 6, 123-133.
Andrade, D. R.; Godinho, H. P.; Ribeiro, S. P. and Castro, E. F. T. (1985), Ciclo reprodutivo anual de lambaris Astyanax bimaculatus (Linnaeus, 1758) em viveiros. Arq. Brás. Méd. Vet. Zoot., 37 : (5), 435347.

Arcifa, M. S.; Northcote, T. G. and Froehlich, O. (1991), Interactive ecology of two cohabiting characin fishes (Astyanax fasciatus and Astyanax bimaculatus) in an eutrophic Brazilian reservoir. $J$. Trop. Ecol., 7, 257-268.

Cowan, J. H.; Rose, K. A. and Houde, E. D. (1997), Size-based foraging success and vulnerability to predation: selection of survivors in individual-based models of larval fish populations. In: Chambers, $\mathrm{C}$. and Trippel, E. A. (Eds.). Early life history and recruitment in fish populations. London : Chapman and Hall. pp. 357-389.

Fugi, R. (1998), Ecologia alimentar de espécies endêmicas de lambaris do trecho médio da bacia do rio Iguaçu. $\mathrm{PhD}$ Thesis, Universidade Federal de São Carlos, São Carlos, Brasil.

Garutti, V. and Britski, H. A. (2000), Descrição de uma espécie nova de Astyanax (Teleostei: Characidae) da bacia do alto rio Paraná e considerações sobre as demais espécies do gênero na bacia. Comun. Mus. Ciênc. Tecnol. PUCRS. Ser. Zool., 13, 65-88.

Hahn, N. S.; Andrian, I. F.; Fugi, R. and Almeida. (1997), Ecologia trófica. In: Vazzoler, A. E. A. M.; Agostinho, A. A and Hanh, N. S. (Eds.). A planície de inundação do alto rio Paraná: aspectos físicos, biológicos e socioeconômicos. Maringá : EDUEM. pp. 209-228.

Luiz, E. A.; Agostinho, A. A.; Gomes, L. C. and Hahn, N. S. (1998), Ecologia trófica de peixes em dois riachos da bacia do rio Paraná. Revista Brasileira de Biologia, 58 : (2), 273-285.

Luiz, E. A. (2000), Assembléias de peixes de pequenos reservatórios hidrelétricos do Estado do Paraná. Maringá. Dissertação de Mestrado. Universidade Estadual de Maringá, Maringá, Brasil.

Okada, K. O.; Agostinho, A. A.; Petrere Jr, M. and Penczak, T. (2003). Factors affecting fish diversity and abundance in drying pools and lagoons in the upper Paraná river basin, Brazil. Ecohydrology $e$ Hydrobiology, 3 : (1), 97-110.

Paiva, M. P. (1982), Grandes Represas do Brasil. Brasília : Editerra. 292 pp.

Rodrigues, A. M.; Campos. E. C. and Ferreira, A. E. (1989), Aspectos da estrutura populacional e época de reprodução do tambiú Astyanax bimaculatus (Characiformes, Characidae) na represa de Bariri, Rio Tietê, Estado de São Paulo, Brasil. B. Inst. Pesca, 16 : (1), 97-110. 
Rodrigues, A. M.; Santos Giamas, M. T. D.; Campos, E. C. and Camara, J. J. C. (1995), Tipo de desova e fecundidade do lambari prata Astyanax schubarti Britski, 1964 (Pisces, Characiformes, Characidae), na represa de Ibitinga, Estado de São Paulo, Brasil. B. Inst. Pesca, 22 : (1), 133-139.

Suzuki, H. I. and Agostinho, A. A. (1997), Reprodução de peixes do reservatório de Segredo. In: Agostinho, A. A. and Gomes, L. C. (Eds.). Reservatório de Segredo: bases ecológicas para o manejo. Maringá : EDUEM. pp. 163-182.

Suzuki, H. I. (1999), Estratégias reprodutivas de peixes relacionadas ao sucesso na colonização em dois reservatórios do rio Iguaçu. $\mathrm{PhD}$ Thesis, Universidade Federal de São Carlos, São Carlos, Brasil.

UEM/NUPELIA (1997) Estudos ictiológicos na área de influência do AHE Corumbá (fase rio), Relatório parcial (março-agosto/96). Relatório. Apoio Furnas Centrais Elétricas. Maringá : UEM. 289 pp.

UEM/NUPELIA (2001) Estudos ictiológicos na área de influência do AHE Corumbá. (Relatório final). Relatório. Furnas Centrais Elétricas. Maringá : UEM. 370 pp.

Vazzoler, A. E. A. M. (1996), Biologia da reprodução de peixes teleósteos: teoria e prática. Maringá : EDUEM. 169 pp.

Vazzoler, A. E. A. M.; Suzuki, H. I.; Marques, E. E. and Lizama-Peres, M. A. (1997), Primeira maturação gonadal, períodos e áreas de reprodução. In: Vazzoler, A. E. M. A.; Agostinho, A. A. and Hahn, N. S. (Eds.). A Planície de Inundação do Alto Rio Paraná: aspectos físicos, biológicos e socioeconômico. Maringá : EDUEM. pp. 249-265.

Wetzel, R. G. (1990), Reservoir ecosystems: conclusions and speculations. In: Thornton, K. W.; Kimmel, B. L. and Payne, F. E. (Eds.). Reservoir Limnology: ecological perspectives. New York : A Wiley-Interscience. pp. 227-238.

Received: July 18, 2003; Revised: November 24, 2003; Accepted: September 14, 2004. 